\title{
Sigmund Freud
}

\section{Neitun}

Sitthvað má af pví leiða hvernig sjúklingar okkar segja frá hugdettum sínum í sálgreiningartímum. ${ }^{1}$ „Nú haldið pér að ég xtli að fara að segja eitthvað móðgandi, en mér er svo sannarlega ekkert slíkt í huga“. Við áttum okkur á að petta er höfnun í formi frávarps á hugsun sem nú hefur skotið upp kolli. Еða: „Рér eruð að spyrja um hver petta geti verið í draumnum. Pað er $e k k i$ mamma“. Við leiðréttum: „Svo að pað er pá mamma hans“. Við tökum okkur pað bessaleyfi að sniðganga neitunina og nota einungis efnislega merkingu hugrenningartengslanna. Раð er eins og sjúklingurinn hefði sagt: „Раð er alveg rétt, mér datt mamma í hug pegar ég fór að hugsa um pessa manneskju, en ég kæri mig ekki um að láta pá hugsun gilda“.2

Stundum er hægt með afar handhægri aðferð að afla sér peirrar vitneskju sem parf um bælt dulvitað efni. „Нvað“, spyrjum við, „pætti yður allra ólíklegast í pessum aðstæðum? Hvað haldið pér að pér hefðuð síst af öllu hugsað?" Ef sjúklingurinn lætur veiðast í gildruna og segir hvað honum finnist ósennilegast, hefur rétta játningin oftast nær fengist. Skemmtilega gagnstæðu við pessa tilraun er oft að fá hjá áráttusjúklingi sem er búinn að fá nokkra fræðslu um merkingu sjúkdómseinkenna sinna. „Ég er kominn með

1 [Pessi ritgerð var skrifuð í júlímánuði 1924 en hún birtist fyrst á prenti árið 1925 undir heitinu „Die Verneinung“ í tímaritinu Imago 11 (3), bls. 217-221. Hún geymir tvö megin efnisatriði. Upphaf hennar og endir eru tæknilegs eðlis, pað er útskýring á „neitun“ sjúklings, hvernig beri að skilja hana og komast að merkingu hennar í meðferðinni. Аð öðru leyti er efnið metasálfræðilegs eðlis og fjallar um upptök og hlutverk hugsunar (dómgreindar). Par er haldið áfram umræðuefni úr ritgerðunum „Formulierungen über die zwei Prinzipien des psychischen Geschehens“ (1911) og „Metapsychologische Ergänzung der Traumlehre“ (1917). - Pýðandi.]

2 [Áður hafði Freud meðal annars vakið athygli á pessu í sjúkrasögu sinni af „Rottumanninum“ („Bemerkungen über einen Fall von Zwangsneurose“, 1909). - Рýðandi.]

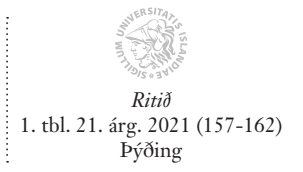

(C) 2021 Ritið, tímarit Hugvísindastofnunar og höfundur greinarinnar

Útgefandi:

Hugvísindastofnun Háskóla Íslands, Sæmundargötu 2, 102 Reykjavík
Birtist á vefnum http://www.ritid.hi.is. Tengiliður: ritið@hi.is

DOI: $10.33112 /$ ritid.21.1.9

Birt samkvæmt skilmálum Creative Commons BY (4.0). 
nýja práhyggju“, segir hann, „og mér datt samstundis í hug að hún kynni að pýða petta eða eitthvað annað. En pað getur ekki verið rétt eða mér gæti ekki hafa dottið pað í hug“. Af meðferðinni má ráða að pað sem hann er hér að hafna er auðvitað hin rétta merking práhyggjunnar.

Pannig er pað pá að ímynd eða hugsun getur fundið sér leið til meðvitundar svo fremi að henni sé neitað. ${ }^{3}$ Neitun er leið til að kynnast pví sem bælt er. Raunar léttir hún pegar á bælingunni, pó að auðvitað sé ekki par með sagt að hún fallist á pað sem var bælt. Hér má sjá hvernig vitsmunirnir skiljast frá tilfinningum. Fyrir tilstyrk neitunarinnar er aðeins annarri af afleiðingum bælingarinnar eytt, pví að hugsunarhluti hins bælda kemst ekki til vitundar. Árangur pess verður eins konar vitsmunaleg viðtaka hins bælda, en aðalatriði bælingarinnar heldur áfram. ${ }^{4}$ Í meðferðinni búum við síðan oft til mjög mikilvægt og fremur undarlegt afbrigði pessa. Okkur tekst líka að sigrast á neituninni og fá fullkomna vitsmunalega viðtöku hins bælda. En pað ýtir pó ekki til hliðar bælingarferlinu sjálfu.

Úr pví að pað er hlutverk dómgreindarinnar að játa eða neita tiltekinni hugsun leiðir pað sem við höfum verið að segja okkur að sálrænum uppruna pess hlutverks eða starfsemi. Аð neita einhverju með dómgreind sinni er pegar öllu er á botninn hvolft sama og að segja: „Petta vildi ég helst bæla“. Neikvætt mat er vitsmunalegur staðgengill bælingar; ${ }^{5}$ „neiið“ pess er kennimark bælingarinnar, upprunavottorð - líkt og Made in Germany ${ }^{6}$ - skulum við segja. Fyrir tilstyrk neitunartáknsins leysir hugsunin sig undan takmörkunum bælingarinnar og bætir við sig efni sem henni er nauðsynlegt til eðlilegrar starfsemi sinnar.

[Hér getur verið álitamál hvort réttara er að pýða með „neita“ en „afneita“. Að sumu leyti gæti virst eðlilegra að pýða með „afneita“, en pá er pess að gæta að Freud notar sjálfur tvö orð: verneinen (neita) og verleugnen (afneita). Fyrra orðið notar hann í pessari ritgerð. - Рýðandi.]

4 [Hér er um pað sama að ræða og pað sem liggur til grundvallar alkunnri hjátrú að varasamt sé að hrósa sigri. „Mikið er gott að ég skuli ekki hafa fengið neinn höfuðverk í dag“. En í rauninni er petta fyrsta tilkynningin um höfuðverkjarkast sem viðkomandi er pegar farinn að finna að er í aðsigi, pó að hann vilji enn ekki trúa pví. Freud datt fyrst niður á bessa skýringu í meðferð á frú Cäcilie M., sem var einn af fyrstu sjúklingum hans eða að minnsta kosti fyrsta skráða sjúkrasaga hans. Sjá bók Sigmunds Freud og Josefs Breuer, Studien über Hysterie, Leipzig og Vín: Franz Deuticke, 1895. - Pýðandi.]

5 [Freud mun fyrst hafa komið pessari hugmynd á framfæri í bók sinni Der Witz und seine Beziebung zum Unbewussten (1905). Aftur kemur hún fyrir í ritgerðinni „Formulierungen über die zwei Prinzipien des psychischen Geschehens“ (1911) og síðan í ritgerðinni „Das Unbewusste“ (1915). - Pýðandi.]

6 [Á ensku í frumtexta. - Pýðandi.] 
Dómgreindin fæst aðallega við tvenns konar ákvarðanir. Hún kveður á um hvort tiltekið fyrirbæri hefur vissa eiginleika eða ekki. Hún segir til um hvort pað sem birtist sé raunverulegt eða ekki. Eiginleikinn sem til mats kemur getur hafa verið í upphafi góður eða vondur, gagnlegur eða skaðlegur. Sé petta sagt á tungu hinnar elstu hvatar - munnhvatarinnar - hljóðar matið svo: „Ég vil éta pað“ eða „ég vil hrækja pví út úr mér“ og með almennara orðalagi: „Ég vildi gjarnan taka petta inn í mig, en halda hinu fyrir utan“. Раð er að segja: „Раð á að vera inni í mér“ eða „pað á að vera fyrir utan mig“. Eins og ég hef sýnt annars staðar vill hið upprunalega vellíðunarsjálf varpa inn í sjálft sig öllu sem er gott en varpa öllu vondu frá sér. Hið vonda, pað sem er sjálfinu framandi og pað sem er fyrir utan var upphaflega eitt og hið sama.?

Hin ákvörðun dómgreindarinnar - hvort pað sem birtist sé raunverulegt (raunveruleikaprófun) - er viðfangsefni hins fullmótaða raunveruleikasjálfs, sem próast í framhaldi af hinu upphaflega vellíðunarsjálfi. Nú er ekki lengur um раð аð ræða hvort раð sem maður hefur skynjað skuli fella inn í sjálfið eða ekki heldur hvort eitthvað sem birst hefur í sjálfinu geti einnig birst á ný sem skynjun (raunveruleg). Eins og við sjáum er hér um að ræða hvað er utan við og hvað fyrir innan. Рað sem er óraunverulegt, einungis birting og hún huglæg, er aðeins til hið innra; pað sem er raunverulegt er aftur á móti einnig parna fyrir utan. Á pessu stigi próunar hefur tillit til vellíðunarlögmálsins verið lagt til hliðar. Reynslan hefur kennt viðkomandi að pað skiptir ekki aðeins máli hvort eitthvað (viðfang sem veitir honum fullnægingu) hefur til að bera "góðan“ eiginleika og eigi pví skilið innlimun í sjálf hans heldur líka hvort pað sé til í umheiminum, svo að hægt sé að ná til pess pegar pörf krefur. Til pess að skilja petta framfaraskref verður að minnast pess að öll birting á rætur sínar í skynjunum og er endurtekning á peim. Upphaflega var pví birtingin trygging fyrir að pað sem birtist væri raunverulegt. Andstæðurnar milli hins huglæga og hlutlæga voru ekki til í upphafi. Pær urðu til við að hugsunin varð búin peim eiginleikum að geta birt mönnum á ný fyrir hugarsjónum pað sem eitt sinn var skynjað með pví að sýna pað aftur, án pess að hið ytra viðfang purfi enn að vera til staðar. Fyrsta og beina stefnumark raunveruleikaprófunar er bví ekki að finna raunverulegt skynjað viðfang heldur finna slíkt viðfang á ný til pess að sannfærast

Sjá um petta umræðu [í ritgerð minni] „Triebe und Triebschicksale“ (1915). [Freud fjallaði svo á ný um petta í fyrsta kafla rits síns Undir oki siðmenningar, Reykjavík: Hið íslenska bókmenntafélag, 1990. - Pýðandi.] 
um að pað sé enn parna. ${ }^{8}$ Hugsunin býr ennfremur yfir getu til að greina enn frekar á milli hins huglæga og hlutlæga. Ekki er skynjunin sem birtist aftur alltaf trúverðug. Hún kann að breytast við að sleppt er úr eða við að blandast ýmsu öðru. Pá parf raunveruleikaprófunin að ganga úr skugga um hversu mikil brenglun hefur orðið. En ljóst má vera að forsendan fyrir pví að koma á raunveruleikaprófun er að viðföng sem eitt sinn veittu fullnægingu hafi glatast.

Dómgreindin er vitsmunastarf sem kveður á um hvað gert skuli. Hún bindur enda á frestunina sem felst í hugsun og leiðir frá hugsun til athafnar. Annars staðar hef ég rætt pessa frestun vegna hugsunar. ${ }^{9}$ Líta má á hana sem tilraunaathöfn, preifingar, sem parfnast lítillar orku. Lítum á hvar sjálfið hefur beitt svipuðum preifingum áður, hvar pað lærði aðferðina sem pað notar nú við hugsunina. Раð varð við skynmörk sálartækisins í tengslum við skynjanir. Pví að samkvæmt tilgátu okkar er skynjun ekki alfarið polrænt ferli. Sjálfið sendir reglulega frá sér litla orkuskammta inn í skynjunarkerfið og með pví móti getur bað tekið sýni úr ytri áreitum og dregið sig aftur til baka eftir slíkar preifingar.

Rannsókn á dómgreindinni sýnir okkur líklega í fyrsta sinn hvernig vitsmunaleg starfsemi sprettur upp í samspili frumhvatanna. Dómgreindarstarfsemin er viðeigandi framhald af pví frumferli sjálfsins að innlima eða varpa frá sér samkvæmt vellíðunarlögmálinu. Tvískautun dómgreindarinnar svarar til andstæðnanna milli hinna tveggja hvataflokka sem við höfum gert ráð fyrir. Játun - sem staðgengill sameiningar - tilheyrir Erosi; neitun - arftaki fráhrindingar - tilheyrir eyðileggingarhvötinni. Löngunina til að neita, neikvæðnina sem sjá má hjá sumu geðveiku fólki, ber líklega að líta á sem merki um að eðlishvatirnar hafi losnað í sundur vegna pess að líbídóhlutarnir hafa verið dregnir til baka. En dómgreindin getur ekki tekið til starfa fyrr en neitunartáknið hefur veitt hugsuninni fyrstu frelsisögnina undan afleiðingum bælingar og ásamt peim undan nauðung vellíðunarlögmálsins.

8 [Petta er varla auðskilin framsetning. En rökfærslan sem hún byggist á á sér langan aðdraganda í skrifum Freuds. Hún kemur fyrst fram í hinni merkilegu ritgerð hans „Entwurf einer Psychologie“ frá 1895 (sem kom fyrst á prent árið 1950 í Aus den Anfängen der Psychoanalyse) og síðar í hinum fræga (og tormelta) síðasta kafla í bók hans Draumaráðningum (Reykjavík: Skrudda, 2010). Viðfangið sem hér er talað um að finna á ný er móðurbrjóstið. - Pýðandi.]

9 [Til að mynda í ritgerðinni „Sjálfið og paðið“, Ritgerðir, Reykjavík: Hið íslenska bókmenntafélag, 2002. Raunar víðar, allt frá „Entwurf einer Psychologie“ til Nýrra inngangsfyrirlestra um sálkönnun, Reykjavík: Hið íslenska bókmenntafélag, 1997. Pýðandi.] 
Petta viðhorf til neitunar er í afar góðu samræmi við að í sálgreiningarmeðferð finnst aldrei „nei“ í dulvitundinni og að sjálfið tjáir með neikvæðri formúlu viðtöku sína á dulvituðu efni. Betri sönnun fyrir pví að lánast hefur að lyfta hulu af dulvitund er ekki hægt að fá en pegar sjúklingurinn bregst við með pví að segja: „Рað hugsaði ég ekki“ eða „aldrei hefði mér dottið pað í hug". ${ }^{10}$

Sigurjón Björnsson pýddi

10 [Petta sagði Freud með næstum sömu orðum í neðanmálsgrein frá 1923 í sjúkrasögunni af Dóru („Sálgreining á sefasýki“, Sjúkrasögur, Reykjavík: Hið íslenska bókmenntafélag, 2004 og einnig löngu síðar í ritgerðinni „Konstruktionen in der Aanalyse“ (1937). - Pýðandi.] 
